\title{
Investigation of Heavy Metal Accumulation in Vegetables and Health Risk to Humans From Their Consumption
}

\begin{abstract}
Neha Gupta ${ }^{1 *}$ Krishna Kumar Yadav ${ }^{2}$, Vinit Kumar ${ }^{1}$, Shiv Prasad ${ }^{3}$, Marina M. S. Cabral-Pinto ${ }^{4}$, Byong-Hun Jeon ${ }^{5}$, Sandeep Kumar ${ }^{4}$, Magda H. Abdellattif ${ }^{6}$ and Abdulmohsen Khalaf Dhahi Alsukaibia ${ }^{7}$

'Institute of Environment and Development Studies, Bundelkhand University, Jhansi, India, ${ }^{2}$ Faculty of Science and Technology, Madhyanchal Professional University, Bhopal, India, ${ }^{3}$ Division of Environment Science, ICAR-Indian Agricultural Research Institute, New Delhi, India, ${ }^{4}$ Geobiotec Research Centre, Department of Geosciences, University of Aveiro, Aveiro, Portugal, ${ }^{5}$ Department of Earth Resources and Environmental Engineering, Hanyang University, Seoul, South Korea, ${ }^{6}$ Department of Chemistry, College of Science, Taif University, Taif, Saudi Arabia, ${ }^{7}$ Department of Chemistry, Faculty of Science, University of Hail, Hail, Saudi Arabia
\end{abstract}

OPEN ACCESS

Edited by:

C. Mariorie Aelion,

University of Massachusetts Amherst,

United States

Reviewed by:

Avinash Kaur Nagpal,

Guru Nanak Dev University, India

Sazal Kumar,

South China Sea Institute of

Oceanology (CAS), China

${ }^{*}$ Correspondence:

Neha Gupta

nhgupta83@gmail.com

Specialty section:

This article was submitted to Toxicology, Pollution and the

Environment,

a section of the journal

Frontiers in Environmental Science

Received: 07 October 2021

Accepted: 17 January 2022

Published: 21 February 2022

Citation:

Gupta N, Yadav KK, Kumar V,

Prasad S, Cabral-Pinto MMS, Jeon B-H, Kumar S, Abdellattif MH and Alsukaibia AKD (2022) Investigation of

Heavy Metal Accumulation in Vegetables and Health Risk to Humans

From Their Consumption.

Front. Environ. Sci. 10:791052.

doi: 10.3389/fenvs.2022.791052
Heavy metals contamination of soil and edible parts of vegetables is presently a challenging environmental issue worldwide. The present study determined the accumulated amount of cadmium (Cd), lead (Pb), nickel (Ni), cobalt (Co), zinc (Zn), copper (Cu), and manganese (Mn) in soil, coriander, onion, and tomato collected from agricultural fields of Jhansi city, India. The bioconcentration factor and non-carcinogenic health risks were also assessed to know the vegetables' accumulation potential of heavy metals from soil and possibility to have noncarcinogenic health risks via an intake of these vegetables. The samples were digested using diacid solution prior to heavy metals analysis by atomic absorption spectrometric method. The average content of $\mathrm{Cd}, \mathrm{Pb}, \mathrm{Ni}, \mathrm{Co}, \mathrm{Zn}, \mathrm{Cu}$, and $\mathrm{Mn}$ were 2.02, 19.09, 21.56, 9.31, 35.34, 14.96 , and $15.21 \mathrm{mg} / \mathrm{kg}$ dry weight (dw) in soil, $0.23,2.12,0.77,0.47,36.65,5.92$, and $21.65 \mathrm{mg} / \mathrm{kg}$ dw in coriander, $0.13,0.66,0.54,0.32,23.94,6.25$, and $20.15 \mathrm{mg} / \mathrm{kg} \mathrm{dw}$ in onion, $0.14,0.46,0.89,0.22,16.77,4.77$, and $14.46 \mathrm{mg} / \mathrm{kg} \mathrm{dw}$ in tomato, respectively. The bio-concentration factor revealed significant accumulation of $\mathrm{Zn}$ (1.04) and $\mathrm{Mn}$ in coriander (1.42), and in onion (1.32). The target hazard quotient and health risk index signaled that the population consuming these vegetables is risk-free. However, it is recommended that the concentration of heavy metals in the soil and crops of the study area and its related health risks be regularly monitored to avoid significant health risks in the future.

Keywords: heavy metals, hazard quotient, risk index, vegetables, accumulation

\section{INTRODUCTION}

Heavy metals and metalloids are the natural and structural part of the earth's crust with a density greater than $5 \mathrm{~g} / \mathrm{cm}^{3}$. Many of them are environmentally persistent and non-degradable contaminants. Initially, they are deposited on the soil surface, then absorbed by the apoplast of plant roots and further distributed and accumulated into their edible and non-edible parts, posing an imminent danger to the food chain (Ahmad et al., 2019; Alsafran et al., 2021). A very less amount of heavy metals can also be taken up by vegetables by atmospheric deposition (Prasad et al., 2021). Vegetables are major part of human platter as 
they have high amounts of fibers, minerals, vitamins, and antioxidants. Therefore, heavy metals contamination of vegetables cannot be ignored due to their significance in food quality assurance. Furthermore, the food chain pyramid is the track by which biologically toxic trace metals accumulated in humans and other animals (Gupta et al., 2019; Prasad et al., 2021).

Urban areas of developing countries like Pakistan (Alam et al., 2018), Bangladesh (Islam et al., 2016), Ethiopia (Gebeyehu and Bayissa, 2020), Ghana (Ametepey et al., 2018), South Africa (Fonge et al., 2021), and India (Yadav et al., 2015) reported to have high heavy metal levels due to rapid industrialization, wastewater irrigation, and other anthropogenic activities. Since seventy percent of the water is used for the agricultural sector (FAO, 2017), reuse of recycled wastewater for this purpose plays a significant role to achieve agriculture sustainability. Nevertheless, even recycled wastewater contains some pollutants including heavy metals and contaminates the soil and plants (Zwolak et al., 2019). In addition, petrochemical activities also increase soil contamination due to multiple oil spills incidences, waste disposals, chemical discharge, and gas flaring into the environment and may pose serious health issues to the ecosystem and human population (Sun et al., 2019). Furthermore, gasoline may also contribute to the increased concentrations of certain heavy metals such as $\mathrm{Cd}, \mathrm{Pb}, \mathrm{Ni}, \mathrm{Zn}$, and $\mathrm{Cu}$ in roadside soils and thus accumulate in vegetables (Kumar S. et al., 2019). Previous studies have shown that vegetables grown near industrial sites (Haque et al., 2021), mine site (Zhou et al., 2016), highways (Gupta et al., 2021a), and solid waste dump site (Njagi et al., 2017) contained more heavy metals than vegetables grown away from such sites. Hence, vegetables grown near industrial areas, mine sites, highways, and solid waste dump site may pose significant health risk for human beings and animals.

Nowadays, the public awareness of health risks is increasing the risk assessment associated with heavy metals contamination has become one of the hot topics worldwide. Prolonged consumption of high heavy metal levels through contaminated food may cause chronic heavy metals accumulation in humans' liver, kidney, and bones, resulting in kidney, cardiovascular, nervous, and bone diseases (Anwar et al., 2016). In addition, heavy metals may also create congenital disabilities and responsible for low birth weight of born babies $(<2.5 \mathrm{Kg})$ and premature births $(<37$ weeks of completed gestation) (Taylor et al., 2015). Some heavy metals specifically Mn (Flora, 2014), Co (Simonsen et al., 2011), Cu (Wuana and Okieimen, 2011), Ni (Ihedioha et al., 2014), and Zn (Mohammadi et al., 2017) act as essential elements at certain concentrations in humans but they become noxious when exposed to higher doses. Whereas Cd (Khan et al., 2015), Pb (Jaishankar et al., 2014), As (Abdul et al., 2015), and hexavalent chromium [Cr(VI)] (Wang et al., 2017) may cause carcinogenic effects even in trace quantities. In addition, soil contamination with heavy metals is widely reported to cause health hazards (Gupta et al., 2021b). Further insight of meta-analysis into metal uptake by plants and its human health risk still needs to be investigated in India, China, and other countries. Hence, the current study aimed to evaluate the concentrations of $\mathrm{Cd}, \mathrm{Pb}, \mathrm{Ni}, \mathrm{Co}, \mathrm{Zn}, \mathrm{Cu}$, and $\mathrm{Mn}$ in agricultural soil and the edible parts of coriander, onion, and tomato.
Furthermore, the non-carcinogenic risk of vegetable consumption on human health was also assessed to ensure the safety of the people in the vicinity of Jhansi city.

\section{MATERIALS AND METHODS}

\section{Study Area}

This study was conducted at the district of Jhansi, a known historic place in Uttar Pradesh State of India. The city has a historical background because the empress "Rani Lakhsmi Bai" ruled this city in the mid-19th century. This study area is situated between $25^{\circ} 07^{\prime \prime}$ to $25^{\circ} 57^{\prime \prime} \mathrm{N}$ and $78^{\circ} 10^{\prime \prime}$ to $79^{\circ} 25^{\prime \prime} \mathrm{E}$, in Jhansi city, which has an elevation above the mean sea level of $284 \mathrm{~m}$. The average annual rainfall of this city is $885 \mathrm{~mm}$ and type of climate is sub-humid with hot and dry summer and cold winter (CGWB, 2017). Seven sampling sites were chosen for collection of samples on the basis of exposure to vehicular emission from the entire study area (Figure 1). A total of three national highways including $\mathrm{NH}-27$ (from Porbandar to Silchar), NH-44 (from Srinagar to Kanyakumari), and NH39 (from Jhansi to Ranchi) passed through the city. NH-27 adjoins the Jhansi to Kanpur which is a major financial and industrial center of North India and also called the 'Leather City of the World'. The vehicles coming from NH-44 and NH39 pass through the selected sampling points to Kanpur.

\section{Sampling of Soil and Vegetables}

The soil and vegetable samples (coriander, onion, and tomato) were collected during spring and summer seasons from seven farmers' fields near the national highway $\mathrm{NH}-27$, Jhansi city, as depicted in Figure 1. The vegetable samples were collected on the basis of availability in all farmers' fields at the same time. First of all, the soil samples were randomly collected in triplicate at a $0-15 \mathrm{~cm}$ depth using a spade from all selected sampling points. Then, the collected subsamples were mixed together to attain a $1 \mathrm{Kg}$ of representative sample. Finally, soil samples were taken into labeled zippered polyethylene (PE) bags to prevent them from further contamination and immediately taken to the laboratory for further analysis. Similarly, the vegetable samples (edible parts) were also collected from same fields in triplicates and stored in pre-labeled zippered PE bags and taken to the laboratory for further processing. Details of vegetable samples are given in Table 1.

\section{Soil and Vegetable Sample Processing and Experimental Procedure}

The soil samples were dried in air at room temperature to attain a constant weight and ground using mortar and pestle to obtain fine-textured powder. However, in case of vegetables, the collected edible parts were first cut into small pieces using a pre-cleaned stainless steel knife and then dried in the laboratory oven at $75^{\circ} \mathrm{C}$ for 3 days. The dried vegetable samples were uniformly ground using mortar and pestle to fine-textured powder. The grounded fine-textured samples were stored in clean PE bags at room temperature for heavy metals and other 


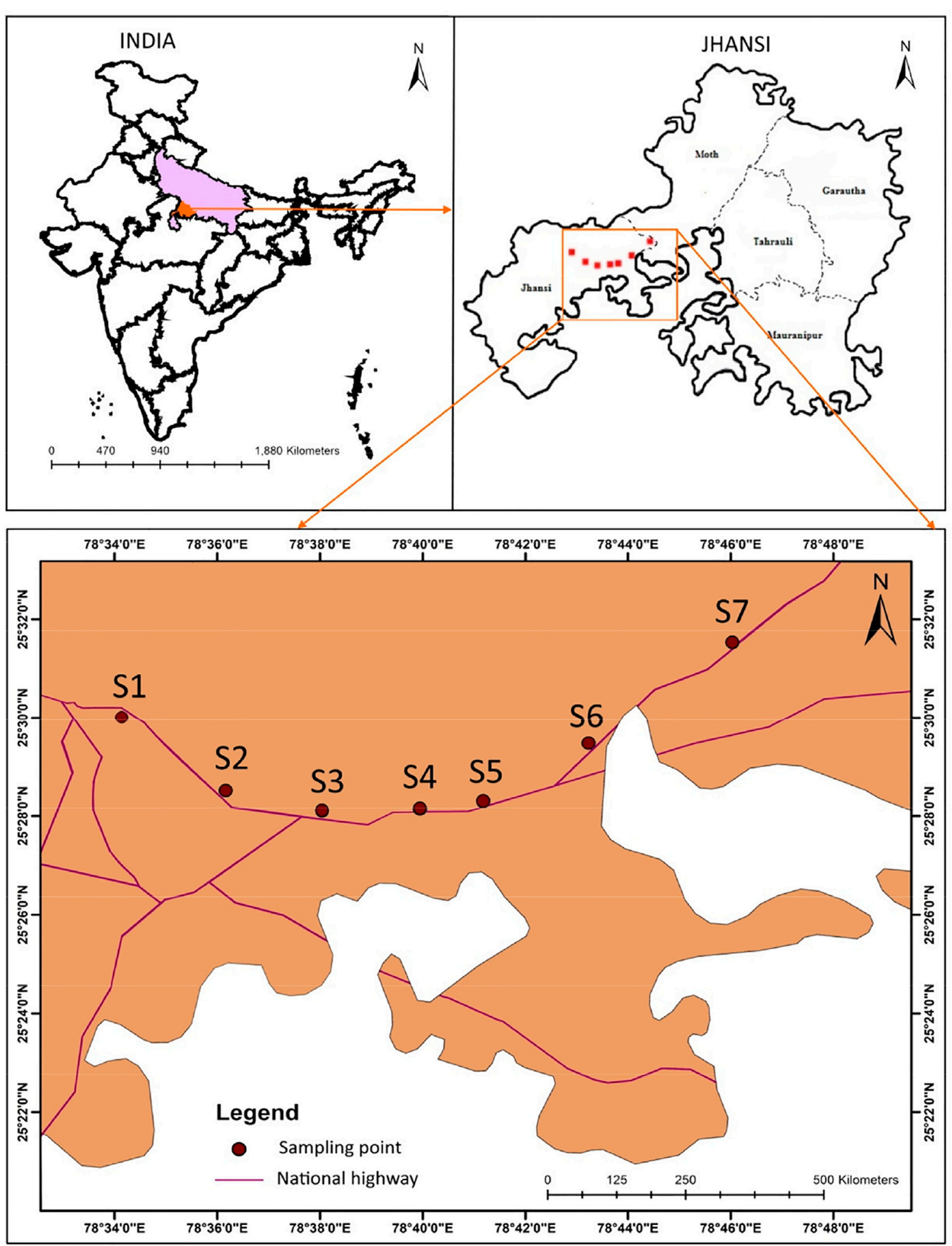

FIGURE 1 | A map of study area showing the locations of sampling points.

parameters analysis. The heavy metals contents were analyzed by atomic absorption spectrometry method using Perkin-Elmer AAnalyst 400, USA model after digestion of samples. The digestion (wet oxidation) process for soil and vegetables samples was done with the help of solution which was prepared by mixing one part of perchloric acid $\left(\mathrm{HClO}_{4}\right)$ and three part of conc. Nitric acid $\left(\mathrm{HNO}_{3}\right)$ (Guo et al., 2006; Singh and Praharaj, 2017). 
TABLE 1 | Details of vegetable samples.

\begin{tabular}{|c|c|c|c|c|}
\hline S. No & Common name & Botanical name & Edible part & Family \\
\hline 1 & Coriander & Coriandrum sativum & Leaves & Apiaceae \\
\hline 2 & Onion & Allium cepa & Bulb & Amaryllidaceae \\
\hline 3 & Tomato & Solanum lycopersicum & Fruit & Solanaceae \\
\hline
\end{tabular}

\section{Quality Check}

The analysis of samples was done for quality control and assurance. The analytical-grade chemicals and reagents were used during entire analytical procedures. Double distilled water (DDW) was applied to prepare the required reagents, standards, and analytical samples processing and dilution. Calibration curves were produced for each investigated heavy metal. Blanks were also analyzed frequently to ensure analytical quality. Procedural washing at regular intervals was done using DDW during the entire analysis to avert any contamination in the equipment. The values of instrumental detection limit (IDL) were lower than the values of method detection limit (MDL) and method quantification limit (MQL) which signaled the good sensitivity of the instrument (atomic absorption spectrophotometer) for heavy metals estimation.

\section{Bio-Concentration Factor of Heavy Metals}

BCF of heavy metals from soils to vegetables was assessed by computing the ratio of the concentration of each heavy metal in vegetable's edible parts and the concentration of corresponding heavy metals in the respective soil. If BCF is less than 1 , it suggests less movement of heavy metals from soil to vegetables. Conversely, BCF of more than one indicate the higher uptake of heavy metals by tested vegetable from soil (Sharma et al., 2018). It was assessed by following Eq. 1.

$$
\text { Bio }- \text { concentration }(\mathrm{BCF})=\mathrm{C}_{\mathrm{V}} / \mathrm{CS}_{\mathrm{S}} .
$$

Where, $\mathrm{C}_{\mathrm{v}}$ is the amount of heavy metals in vegetables on dry weight $(\mathrm{DW})$ basis $(\mathrm{mg} / \mathrm{kg} \mathrm{dw})$, while $\mathrm{C}_{\mathrm{s}}$ is the amount of heavy metals $(\mathrm{mg} / \mathrm{kg} \mathrm{dw})$ in soil samples.

\section{Health Risk Assessment}

The evaluation of possible level of any potentially harmful health effects occurring over a specified time period is known as "risk assessment" (Mohammadi et al., 2019). Based on the assessment of risk level, it can be categorized into carcinogenic and noncarcinogenic risks (Wongsasuluk et al., 2014). Carcinogenic risk assessment is a method of estimating the incremental probability of developing cancer over an individual's lifetime due to exposure to a potential carcinogenic metal (USEPA, 1991). According to IARC (2014), $\mathrm{Cd}, \mathrm{Ni}$, and Co were considered as carcinogenic metals in this study that have the potential to cause cancer when an individual is exposed to them for a lifetime (70 years). However, quantitative assessment of carcinogenic risk from oral exposure to these metals was not performed under the Integrated Risk Information System (IRIS) program (USEPA, 2021). Therefore, the carcinogenic risk assessment was not performed due to non-availability of oral slope factor $\left(\mathrm{SF}_{\mathrm{O}}\right)$ for these metals.

\section{Non-carcinogenic Health Risk Assessment}

The heavy metals' non-carcinogenic risk to humans was determined by assessing the estimated daily intake (EDI) and target hazard quotient (THQ). However, the cumulative noncarcinogenic health hazard posed by exposure to a mixture of all investigated heavy metals was assessed by determining health risk index (HRI). EDI of heavy metals was evaluated using following Eq. 2.

$$
\mathrm{EDI}=\frac{\mathrm{C} \times \mathrm{IR} \times \mathrm{EF} \times \mathrm{ED}}{\mathrm{BW} \times \mathrm{AT}} \times 10^{-3}
$$

Where EDI denotes estimated daily (everyday) intake of heavy metals ( $\mathrm{mg} /$ person/day); BW stands for adult body weight considered as $70 \mathrm{Kg}$ (USEPA, 1989); AT represents the average time of exposure for non-carcinogenic health risk, taken as $\mathrm{ED} \times$ $365=25,550$ days (USEPA, 1989); C signifies heavy metals content in vegetables estimated in the current study $(\mathrm{mg} / \mathrm{kg}$ $\mathrm{dw})$; IR is ingestion rate of vegetables regarded as $65 \mathrm{~g} /$ person/ day for tomato, $60 \mathrm{~g} /$ person/day for onion, and $35 \mathrm{~g} /$ person/day for coriander (survey from local residents); EF and ED refers to the exposure frequency and exposure duration which were assumed as 365 days/year and 70 years, respectively (Sharma et al., 2018).

Target hazard quotient (THQ) measures aggregated noncancerous risks because of heavy metals intake via regular ingestion of contaminated vegetables. THQ values $<1$ are supposed to have no non-carcinogenic risks. While, if the value of THQ $>1$, it is considered to have possibility of substantial health hazards. The health risk hazard is enhanced with the increased THQ (Antoine et al., 2017). THQ was determined by following Eq. 3 .

$$
\mathrm{THQ}=\frac{\mathrm{EDI}}{\mathrm{RfD}}
$$

Where RfD refers to oral reference dose which was taken as $1 \times$ $10^{-3}$ for $\mathrm{Cd}$, $3.5 \times 10^{-3}$ for $\mathrm{Pb}, 2.0 \times 10^{-2}$ for $\mathrm{Ni}, 2.0 \times 10^{-2}$ for $\mathrm{Co}$, $3 \times 10^{-1}$ for $\mathrm{Zn}, 4.0 \times 10^{-1}$ for $\mathrm{Cu}$, and $4.6 \times 10^{-2}$ for Mn (USEPA, 2021).

Health risk index (HRI) was estimated by following Eq. 4 .

$$
\mathrm{HRI}=\sum \mathrm{THQ}
$$

Where THQ represents the target hazard quotient and can be computed by Eq. 3 .

\section{Statistical Analysis}

The data obtained from the experimental analysis was simplified through principal component analysis (PCA) to speculate the sources of heavy metals in the vegetables of the study area. It was 
TABLE 2 | Average concentration ( $\mathrm{mg} / \mathrm{kg}$ ) of heavy metals in soil and vegetable samples of the study area $(\mathrm{N}=28)$ on dry weight (dw) basis.

\begin{tabular}{|c|c|c|c|c|c|c|c|c|}
\hline Samples & Index & Cd & $\mathrm{Pb}$ & $\mathrm{Ni}$ & Co & $\mathrm{Zn}$ & $\mathrm{Cu}$ & Mn \\
\hline \multirow[t]{2}{*}{ Soil } & Mean \pm SD & $2.02 \pm 2.00$ & $19.09 \pm 4.77$ & $21.56 \pm 9.38$ & $9.31 \pm 3.23$ & $35.34 \pm 5.83$ & $14.96 \pm 6.12$ & $15.21 \pm 6.05$ \\
\hline & Range & $0.77-5.06$ & $9.09-22.59$ & $12.21-34.09$ & $6.42-15.02$ & $29.10-41.33$ & $5.57-24.34$ & $9.21-22.20$ \\
\hline \multirow[t]{2}{*}{ Coriander } & Mean \pm SD & $0.23 \pm 0.07$ & $2.12 \pm 2.94$ & $0.77 \pm 0.46$ & $0.47 \pm 0.41$ & $36.65 \pm 6.66$ & $5.92 \pm 1.81$ & $21.65 \pm 7.32$ \\
\hline & Range & $0.14-0.44$ & $0.71-12.52$ & $0.31-2.39$ & $0.03-1.33$ & $26.45-49.70$ & $3.30-10.60$ & $9.33-33.84$ \\
\hline \multirow[t]{2}{*}{ Onion } & Mean \pm SD & $0.13 \pm 0.08$ & $0.66 \pm 0.60$ & $0.54 \pm 0.34$ & $0.32 \pm 0.30$ & $23.94 \pm 7.10$ & $6.25 \pm 3.16$ & $20.15 \pm 7.02$ \\
\hline & Range & $0.00-0.30$ & $0.19-2.21$ & $0.13-1.66$ & $0.03-0.93$ & $9.74-39.46$ & $2.64-13.42$ & $8.13-36.58$ \\
\hline \multirow[t]{2}{*}{ Tomato } & Mean \pm SD & $0.14 \pm 0.08$ & $0.46 \pm 0.50$ & $0.89 \pm 2.19$ & $0.22 \pm 0.25$ & $16.77 \pm 4.97$ & $4.77 \pm 1.82$ & $14.46 \pm 5.01$ \\
\hline & Range & $0.02-0.35$ & $0.03-2.30$ & $0.13-11.88$ & $0.02-0.92$ & $7.81-23.92$ & $0.39-9.83$ & $3.83-22.76$ \\
\hline \multicolumn{2}{|l|}{$\mathrm{BGV}^{\mathrm{a}}$} & 0.90 & 13.10 & 27.70 & 15.20 & 22.10 & 56.50 & 209.00 \\
\hline \multicolumn{2}{|c|}{ USEPA (2002) b } & 0.48 & 200 & 72 & - & 1,100 & 270 & - \\
\hline \multicolumn{2}{|c|}{ Allowable limit ${ }^{\mathrm{C}}$} & $0.05-0.2$ & $0.1-0.3$ & 10 & 50 & 50 & $10-40$ & 500 \\
\hline
\end{tabular}

${ }^{a} B G V$, is the background value for heavy metals in soils in India (Kumar V. et al., 2019); USEPA (2002).

${ }^{b}$ is the standards reference value for heavy metals in agricultural soils.

${ }^{c}$ Allowable heavy metals limit ( $\mathrm{mg} / \mathrm{kg} \mathrm{dw}$ ) in vegetables as described by Gebeyehu and Bayissa, 2020.

\begin{tabular}{|c|c|c|c|c|c|c|c|c|c|}
\hline $\begin{array}{l}\text { Sample } \\
\text { type }\end{array}$ & Cd & $\mathrm{Pb}$ & $\mathbf{N i}$ & Co & $\mathrm{Zn}$ & $\mathrm{Cu}$ & Mn & $\begin{array}{c}\text { Point } \\
\text { of sample } \\
\text { collection }\end{array}$ & References \\
\hline \multirow[t]{4}{*}{ Soil } & 2.02 & 19.09 & 21.56 & 9.31 & 35.34 & 14.96 & 15.21 & Vicinity of highway & Present study \\
\hline & 4.32 & 33.48 & 21.45 & 7.31 & 92.37 & 23.34 & $1,248.69$ & Industrial area & Ashraf et al. (2021) \\
\hline & 1.40 & 77.88 & 68.01 & - & 246.86 & 205.04 & - & Industrial area & Moghtaderi et al. (2018) \\
\hline & - & 1.99 & - & 8.13 & 55.75 & 12.17 & 11.29 & Bank of River & Muhammad et al. (2021) \\
\hline \multirow[t]{3}{*}{ Coriander } & 0.23 & 2.12 & 0.77 & 0.47 & 36.65 & 5.92 & 21.65 & Vicinity of highway & Present study \\
\hline & $\mathrm{BDL}$ & 62.42 & - & - & 49.86 & 21.43 & 142.63 & Waste-water irrigation & Ramesh and Murthy (2012) \\
\hline & - & 6.25 & 9.43 & - & 42.40 & 16.80 & - & Waste-water irrigation & Khan et al. (2018) \\
\hline \multirow[t]{4}{*}{ Onion } & 0.13 & 0.66 & 0.54 & 0.32 & 23.94 & 6.25 & 20.15 & Vicinity of highway & Present study \\
\hline & - & - & 4.74 & - & 33.46 & 70.71 & - & Super-market & Cherfi et al. (2016) \\
\hline & - & 0.45 & - & - & 5.48 & 3.94 & 9.96 & Reference/control site & Filimon et al. (2021) \\
\hline & 0.05 & $\mathrm{BDL}$ & - & - & 0.08 & 0.06 & 0.11 & Local market & Ametepey et al. (2018) \\
\hline \multirow[t]{3}{*}{ Tomato } & 0.14 & 0.46 & 0.89 & 0.22 & 16.77 & 4.77 & 14.46 & Vicinity of highway & Present study \\
\hline & $0.37^{\mathrm{a}}$ & $2.19^{a}$ & - & - & $11.20^{\mathrm{a}}$ & $1.56^{\mathrm{a}}$ & - & Industrial area & Haque et al. (2021) \\
\hline & 0.06 & 0.60 & - & - & 29.80 & 1.28 & - & Local market & Zafarzadeh et al. (2018) \\
\hline
\end{tabular}

${ }^{a}$ Heavy metals concentration in $\mathrm{mg} / \mathrm{kg}$ fresh weight (fw).

analyzed by the software, Statistical Package for Social Sciences (SPSS, Version 20.0). PCA involves extracting linear composites of observed variables. It allows the dataset for dimension reduction while keeping a maximum amount of information.

\section{RESULTS AND DISCUSSION}

\section{Levels of Heavy Metals in Soil}

The concentration levels of heavy metals in soil showed a higher inequality. The average amount of heavy metals in soil decreased in the sequence of $\mathrm{Zn}>\mathrm{Ni}>\mathrm{Pb}>\mathrm{Mn}>\mathrm{Cu}>\mathrm{Co}>\mathrm{Cd}$ (Table 2). The levels of $\mathrm{Ni}, \mathrm{Pb}, \mathrm{Cu}$, and $\mathrm{Zn}$ were noted under the safe limit of India's standards as reported by Awasthi (2000) and USEPA (2002). However, Cd concentration was exceeding USEPA (2002) standards but under the India's standards as reported by Awasthi (2000) for agricultural soils. It is also worth noting that the average contents of $\mathrm{Ni}, \mathrm{Co}, \mathrm{Cu}$, and $\mathrm{Mn}$ were less than the background values of soil of India while $\mathrm{Cd}, \mathrm{Pb}$, and $\mathrm{Zn}$ contents were higher than the background values of soil of India (Table 2). The $\mathrm{Cd}, \mathrm{Co}$, and $\mathrm{Cu}$ concentrations were highest at sampling site three whereas the accumulation of $\mathrm{Zn}$ and $\mathrm{Pb}$ was greatest by the soil of sampling site 5 . Furthermore, the accumulated amount of $\mathrm{Ni}$ and $\mathrm{Mn}$ was richest in the samples picked up from sampling site 2 and 1, respectively. The maximum concentrations of $\mathrm{Cd}$ and $\mathrm{Cu}$ correspond with the results reported in a previous study (Ashraf et al., 2021). The concentration of $\mathrm{Pb}$ may be high due to the accumulation of pollutants from vehicles. The use of lead arsenate pesticides can also increase the concentration of $\mathrm{Pb}$ in the soil. The mean concentration of $\mathrm{Pb}$, 
$\mathrm{Co}, \mathrm{Cu}$, and $\mathrm{Ni}$ attained in the present study was higher than those from the values reported by Muhammad et al. (2021) for agricultural soil samples. In contrast, it was very much lesser than the values reported by Moghtaderi et al. (2018) (Table 3).

\section{Levels of Heavy Metals in Coriander, Onion, and Tomato}

The sequence of average concentrations of heavy metals in coriander exhibited the following pattern: $\mathrm{Zn}>\mathrm{Mn}>\mathrm{Cu}>\mathrm{Pb}>\mathrm{Ni}>\mathrm{Co}>\mathrm{Cd}$. The concentration of $\mathrm{Cu}$ was observed highest at sampling site $\mathrm{S} 5$ and lowest at sampling site S4. The results of this study were several folds lower than the results obtained by Sharma et al. (2016) and Tefera and Teklewold (2021) for coriander leaves and seeds, respectively. In the present study concentration of Mn was found lower $(21.65 \mathrm{mg} / \mathrm{kg}$ $\mathrm{dw}$ ) than the value reported by Ramesh and Murthy (2012). The Cd concentration obtained in the current study $(0.23 \mathrm{mg} / \mathrm{kg} \mathrm{dw})$ exceeded the permissible limit at all sites. When compared with the previous research findings, the Cd values obtained in this study were less than the values reported by Sharma et al. (2016). However, it was higher than that of values reported by Kladsomboon et al. (2020). In our study, Pb concentration was found much higher at all sites than the permissible limit of $0.1-0.3 \mathrm{mg} / \mathrm{kg} \mathrm{dw}$ compared to the value reported by Gebeyehu and Bayissa (2020). However, the present study results resembled the results obtained by Khan et al. (2018). The $\mathrm{Ni}$ content in coriander samples at all sites was found well within the allowable limit of $10 \mathrm{mg} / \mathrm{kg} \mathrm{dw}$ reported by Gebeyehu and Bayissa (2020) for vegetables. Baig et al. (2018) reported that $\mathrm{Ni}$ concentration ranged from $6.14-9.43 \mathrm{mg} / \mathrm{kg} \mathrm{dw}$ in the coriander leaves collected from Punjab, Pakistan (Khan et al., 2018). The mean value of Co was found to be $0.47 \mathrm{mg} / \mathrm{kg} \mathrm{dw}$. Sharma et al. (2016) reported the Co concentration up to $69 \mathrm{mg} / \mathrm{kg} \mathrm{dw}$ in coriander from Punjab, India.

In onion, heavy metals concentration was exhibited in the order of $\mathrm{Zn}>\mathrm{Mn}>\mathrm{Cu}>\mathrm{Pb}>\mathrm{Ni}>\mathrm{Co}>\mathrm{Cd}$. The concentration of $\mathrm{Cu}$ ranged between 2.64 and $13.42 \mathrm{mg} / \mathrm{kg} \mathrm{dw}$ with a mean value of $6.25 \mathrm{mg} / \mathrm{kg}$ dw. Filimon et al. (2021) reported a Cu concentration of $3.94 \mathrm{mg} / \mathrm{kg}$ $\mathrm{dw}$ in onions collected from a copper mining area in Eastern Serbia. The concentration of $\mathrm{Mn}$ in onion in the present study $(20.15 \mathrm{mg} / \mathrm{kg}$ $\mathrm{dw})$ is very much higher than reported in Romania $(0.33-4.07 \mathrm{mg} / \mathrm{kg}$ $\mathrm{dw}$ ) (Manea et al., 2020), Ghana (0.07-0.015 mg/kg dw) (Ametepey et al., 2018); Eastern Serbia (9.96 mg/kg dw) (Filimon et al., 2021), and Nigeria (4.26 mg/kg dw) (Muhammad et al., 2021). The range of $\mathrm{Zn}$ concentration in the present study was close to the results (11.4-25.5 mg/kg dw) obtained by Amin et al. (2013). The greatest amount of $\mathrm{Zn}$ in the present study was noticed at S6. The average concentrations of $\mathrm{Cd}$ in both seasons were much higher than the permissible limit of $0.05 \mathrm{mg} / \mathrm{kg}$ dw set by FAO/WHO (2019) for bulb vegetables. In the present work, the range and mean values of $\mathrm{Cd}$ in onion were in line with the work done by Islam et al. (2016), where the range of Cd was $0.06-0.25 \mathrm{mg} / \mathrm{kg} \mathrm{dw}$ with an average value of $0.14 \mathrm{mg} / \mathrm{kg} \mathrm{dw}$. The concentrations of $\mathrm{Pb}$ in onion at all sites exceeded the allowable limit of $0.1 \mathrm{mg} / \mathrm{kg} \mathrm{dw}$ prescribed by FAO/ WHO (2019) for bulb vegetables. The mean values of $\mathrm{Pb}$ obtained in the present study resemble the results obtained by Islam et al. (2016). Contrary to this, the concentration of $\mathrm{Ni}$ was several folds lower than

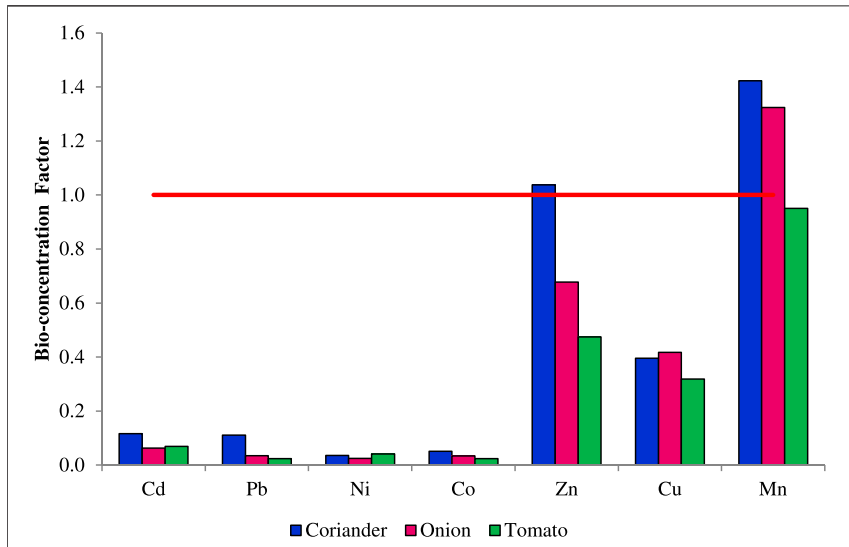

FIGURE 2 | Bio-concentration factor (BCF) of different heavy metals in different vegetables.

reported in France $(4.74 \mathrm{mg} / \mathrm{kg} \mathrm{dw}$ ) (Cherfi et al., 2016). The mean concentration of Co obtained in the present study $(0.32 \mathrm{mg} / \mathrm{kg} \mathrm{dw})$ was much lesser than the results reported by Muhammad et al. (2021).

In tomato, heavy metals accumulation was found in order of $\mathrm{Zn}>\mathrm{Mn}>\mathrm{Cu}>\mathrm{Ni}>\mathrm{Pb}>\mathrm{Co}>\mathrm{Cd}$ as shown in Table 2. However, Cd concentrations exceeded the allowable limit of $0.05 \mathrm{mg} / \mathrm{kg} \mathrm{dw}$ as notified by FAO/WHO (2019) for fruit vegetables. The amount of $\mathrm{Pb}$ and $\mathrm{Ni}$ was found to exceed the allowable limit, as described by Gebeyehu and Bayissa (2020). Co and Mn concentrations were observed many folds less than the permissible limit of FAO/WHO (2019). The level of $\mathrm{Zn}$ in tomatoes varied from 7.81 to $23.92 \mathrm{mg} / \mathrm{kg} \mathrm{dw}$. In this investigation, $\mathrm{Zn}$ in tomatoes was found higher than the value (3.57-9.25 mg/kg dw) reported in Algeria by Bounar et al., 2020. The value for $\mathrm{Zn}$ was slightly lower than that reported in Iran $(29.80 \mathrm{mg} / \mathrm{kg} \mathrm{dw})$ by Zafarzadeh et al., 2018. The $\mathrm{Cu}$ concentration in all samples was well within the prescribed limit of $0.5 \mathrm{mg} / \mathrm{kg} \mathrm{dw}$.

Overall, the ranking of heavy metal concentrations investigated vegetables was as follows: coriander $>$ onion $>$ tomato. It is worth noting that the leafy vegetable coriander has accumulated more amounts of heavy metals followed by onion bulbs and tomato fruits. Similar trends were also reported by Letshwenyo and Mokokwe (2020), Gan et al. (2017), Sharma et al. (2016), and Zhou et al. (2016).

A comparison of the concentrations of $\mathrm{Cd}, \mathrm{Pb}, \mathrm{Ni}, \mathrm{Co}, \mathrm{Zn}, \mathrm{Cu}$, and $\mathrm{Zn}$ in soil and vegetables grown in the present study area with those reported in the literature shows that the heavy metals contents in the study area were lower than those collected from industrial areas or irrigated with wastewater. In contrast, the levels of heavy metals in the study area were higher than those collected from non-industrial areas and local market (Table 3). The heavy metals concentrations in vegetable samples collected from local market might be less due to the fact that local markets have the vegetables from different areas.

\section{The Heavy Metal Bio-Concentration Factors}

The heavy metal BCF is directly proportional to heavy metals in vegetables and their accumulation efficiency. However, it is 
TABLE 4 | Principal component analysis (PCA) of heavy metals for various vegetables.

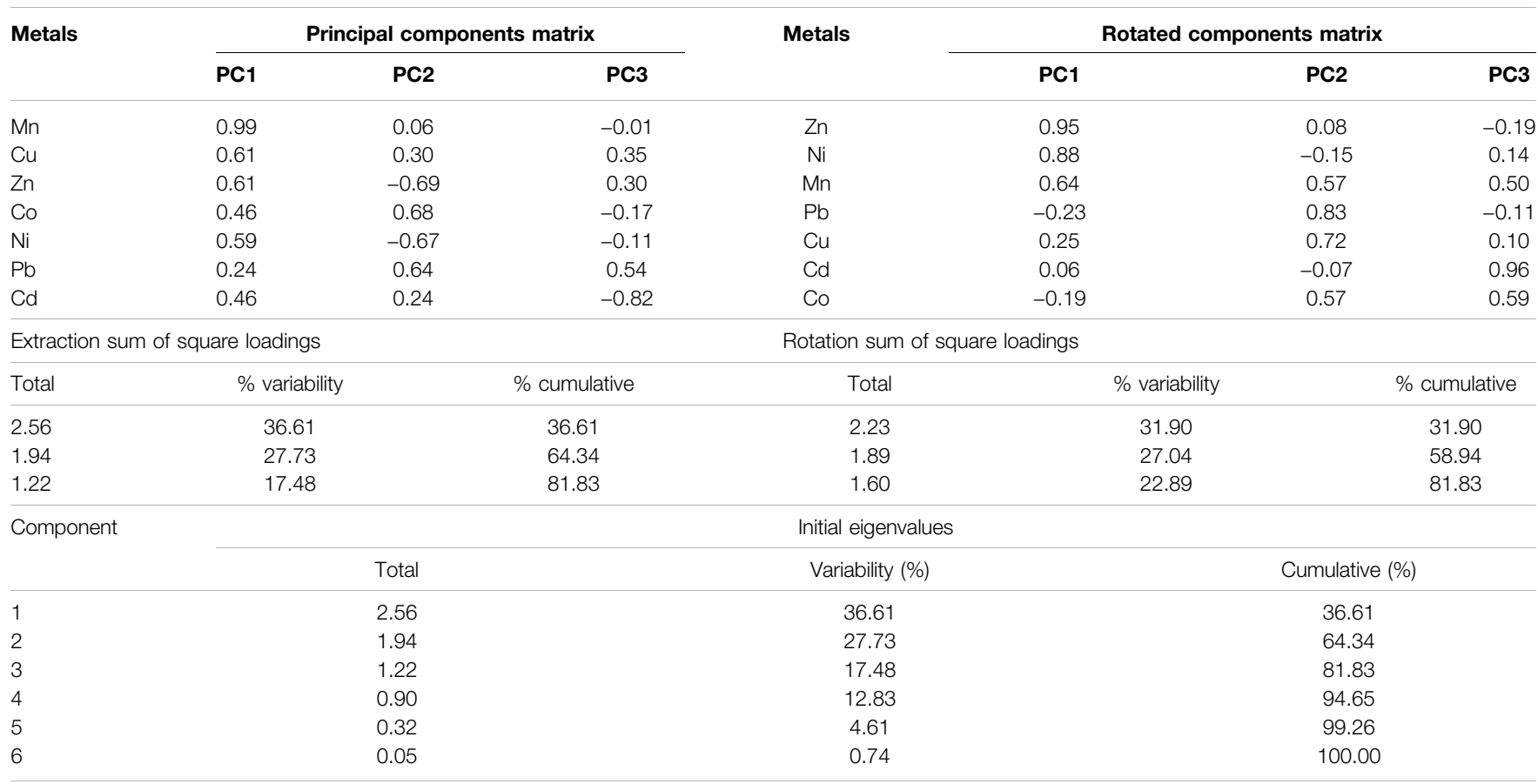

vice versa (inversely proportional) in the case of soil. Therefore, a BCF less than 0.1 suggest that a vegetable eliminates the respective heavy metal from its tissues (leaf, stem, root, fruit, and seed) (Bounar et al., 2020). However, the $\mathrm{BCF} \geq 0.5$ indicates that the soil and vegetables have been started to get contaminated by anthropogenic activities.

BCF of heavy metals were observed in decreasing order of $\mathrm{Mn}>\mathrm{Zn}$ $>\mathrm{Cu}>\mathrm{Cd}>\mathrm{Pb}>\mathrm{Ni}>\mathrm{Co}$ with the highest and lowest values of 1.42 and 0.05 in coriander (Figure 2). The BCF of $\mathrm{Cd}, \mathrm{Pb}, \mathrm{Ni}$, and $\mathrm{Co}$ was $\leq 0.2$ in coriander at all sampling sites. In contrast, BCF of $\mathrm{Cu}$ at sampling site $2(0.52)$ indicates that the site has been started to get contaminated by anthropogenic activities. Hence, it needs an attention to lower the heavy metals concentration in the area. However, the BCF of $\mathrm{Mn}$ and $\mathrm{Zn}$ has surpassed the value of one at almost all selected locations, revealing that the accumulation of heavy metals in coriander was greater than the accumulation in soil.

BCF of heavy metals in the onion bulbs were found in reducing order of $\mathrm{Mn}>\mathrm{Zn}>\mathrm{Cu}>\mathrm{Cd}>\mathrm{Pb}>\mathrm{Co}>\mathrm{Ni}$. It is worth noting that for the onion samples at all sampling sites, $\mathrm{BCF}$ values for $\mathrm{Cd}, \mathrm{Pb}, \mathrm{Ni}$, and Co were $<0.1$ (Figure 2). However, the accumulation of $\mathrm{Mn}$ in onion was higher than the accumulation in the soil at all sampling sites except S3 and S4. The bio-concentration factor for $\mathrm{Zn}$ was higher than 0.50 at all sites except S3 which reveals that accumulation of $\mathrm{Zn}$ has been initiated in onion. Whereas BCF of $\mathrm{Cu}$ was less than 0.50 at all sites except $\mathrm{S} 5$ and $\mathrm{S} 6$. The BCF of heavy metals in tomato were ranked as $\mathrm{Mn}>\mathrm{Zn}>\mathrm{Cu}>\mathrm{Cd}>\mathrm{Ni}>\mathrm{Pb}>\mathrm{Co}$ (Figure 2). However, $\mathrm{BCF}$ of all heavy metals were below the value of one which signifies less accumulation of these heavy metals in tomato. The research findings revealed that heavy metals accumulation varies in these vegetables. However, it was found that leafy vegetable coriander accumulates greater amounts of heavy metals than the onion bulb and tomato fruits.

\section{Principal Component Analysis of Heavy Metals in Vegetables}

Principal component analysis by varimax rotation method was applied on the data set of seven heavy metals to assume the sources of these metals in vegetables. The data extracted from PCA is given in Table 4, including component matrix, rotated component matrix, extraction sum of squared loadings, rotation sums of squared loadings, and initial eigenvalues. The first three principal components (PCs) accounted for $81.83 \%$ of the total variability. The first PC (PC-1) explained $36.61 \%$ with significant + ve loadings of $\mathrm{Mn}(0.99), \mathrm{Cu}(0.61), \mathrm{Zn}(0.61)$, and $\mathrm{Ni}$ (0.59). The contamination of $\mathrm{Cu}$ can occur due to the friction material used in the brake system of vehicles (Adamiec et al., 2016). However, tire wearing and corrosion of galvanized parts might contribute to the raised concentration of $\mathrm{Zn}$ (Taylor and Kruger, 2020). Currently, $\mathrm{Zn}$ is preferred for making wheel balancing weights to avoid leaded-wheel balancing weights. Besides the vehicular emission, a manufacturing unit of Portland cement (Mycem) is also situated in the study area which might be responsible for an elevated content of $\mathrm{Cu}, \mathrm{Ni}, \mathrm{Co}$, and $\mathrm{Pb}$. The cement plants use these metals as catalysts, modifiers, and dryers in the manufacturing process (Jan et al., 2010). In addition to this, a single super phosphate fertilizer industry is also located in the study area which might be responsible for the increased concentration of $\mathrm{Zn}$ and $\mathrm{Pb}$ in the study area. These facts signify that these heavy metals exist in the vegetables due to humaninduced activities. It may include frequent chemical fertilizers and pesticides, vehicular emission, industrial discharge, etc. The 


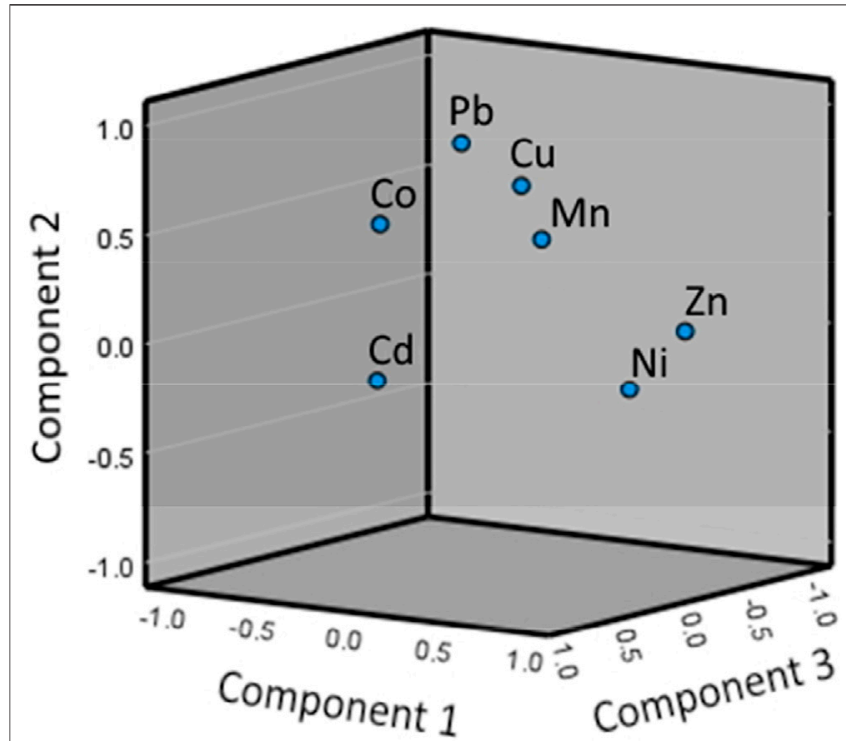

FIGURE 3 | The component plot in rotated space for heavy metals in the study area.

contribution of PC-2 was $27.73 \%$ to the total variance with high + ve loadings of $\mathrm{Co}(0.68)$ and $\mathrm{Pb}(0.64)$. Contrary to this, PC-2 was negatively loaded with $\mathrm{Zn}$ and $\mathrm{Ni}$. However, the data showed that $\mathrm{Cd}$ and Co had a mixed source of origin in the study area (Figure 3).

\section{Non-Carcinogenic Health Risks}

The order of heavy metals with respect to EDI in coriander and onion is $\mathrm{Zn}>\mathrm{Mn}>\mathrm{Cu}>\mathrm{Pb}>\mathrm{Ni}>\mathrm{Co}>\mathrm{Cd}$. However, for tomato, EDI of heavy metals was found in order of $\mathrm{Zn}>\mathrm{Mn}>\mathrm{Cu}>\mathrm{Ni}>\mathrm{Pb}>\mathrm{Co}>$ $\mathrm{Cd}$ (Table 5). The results revealed that EDI of $\mathrm{Cd}, \mathrm{Pb}, \mathrm{Zn}$, and $\mathrm{Cu}$ for coriander, onion, and tomato were within the provisional maximum tolerable daily intake (PMTDI) values as notified by FAO/WHO (2019). The highest and lowest EDI of $\mathrm{Cu}, \mathrm{Mn}, \mathrm{Zn}, \mathrm{Cd}, \mathrm{Pb}, \mathrm{Ni}$, and $\mathrm{Co}$ in coriander were $3.86 \mathrm{E}-03$ at $\mathrm{S} 2$ and $2.11 \mathrm{E}-03$ at $\mathrm{S} 6,1.41 \mathrm{E}-02$ at $\mathrm{S} 2$ and $6.77 \mathrm{E}-03$ at $\mathrm{S} 6,2.42 \mathrm{E}-02$ at S7, and $1.49 \mathrm{E}-02$ at S1, 1.63E-04 at S2 and 7.95-05 at S6, 2.07E-03 at S4 and 4.31E-04 at S5, 7.70E-04 at S2 and 2.56E-04 at S3, and 5.65E-04 at S2 and 3.54E-05 at S5, respectively (Figures $4 \mathbf{A}, \mathbf{B}$ ). It is worth noting that the EDI of all metals was highest at S2 except $\mathrm{Zn}$ and $\mathrm{Pb}$ in coriander which indicated the maximum involvement of human activities in the area. However, the $\mathrm{EDI}$ of $\mathrm{Cu}, \mathrm{Mn}, \mathrm{Zn}, \mathrm{Cd}, \mathrm{Pb}, \mathrm{Ni}$, and $\mathrm{Co}$ in onion were varied from 3.23E-03-8.68E-03, 9.11E-03-2.47E-02, 1.1. E02-2.75E-02, 4.18E-06-1.73E-04, 2.00E-04-1.32E-03, $1.58 \mathrm{E}-$ 04-8.93E-04, and 4.14E-05-6.13E-04, respectively (Figures 5A,B) It is worthy to note that the sequence of EDI of heavy metals in coriander and onion was similar, but the contribution was different. The maximum and minimum EDI values for $\mathrm{Cu}, \mathrm{Mn}, \mathrm{Zn}, \mathrm{Cd}, \mathrm{Pb}, \mathrm{Ni}$, and Co, of tomato, was 7.10E-03 at S2 and 2.75E-03 at S7, 1.80E-02 at S2 and $1.05 \mathrm{E}-03$ at S1, 1.93E-02 at S3, and 8.52E-03 at S4, 2.43E-04 at S1 and 2.36E-05 at S5, 1.34E-03 at S2 and 3.81E-05 at S7, 3.38E-03 at S7 and $1.64 \mathrm{E}-04$ at S5, and 5.45E-04 at S2 and $1.85 \mathrm{E}-05$ at S6, respectively (Figures 6A,B).

The THQ of heavy metals resulting from coriander leaves intake was found to follow decreasing order of $\mathrm{Pb}>\mathrm{Mn}>\mathrm{Cd}>$
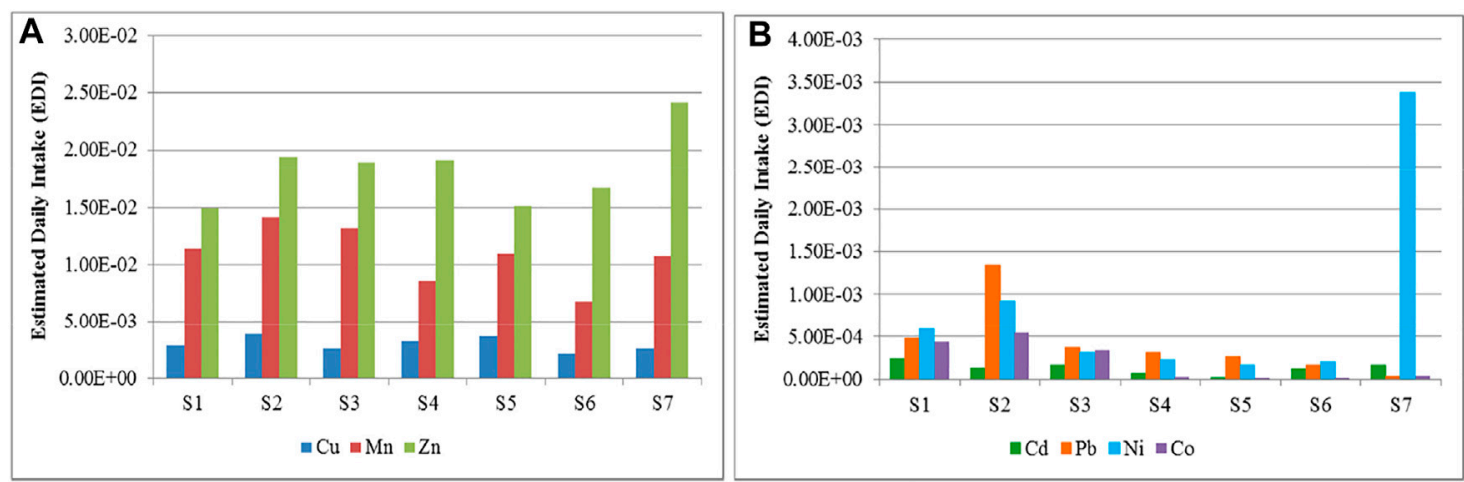

FIGURE 4 | (A,B) EDI of heavy metals in coriander at different sampling sites.

TABLE 5 | EDI due to consumption of different vegetables by adults.

Vegetables

\begin{tabular}{lcc}
\cline { 2 - 3 } & $\mathbf{C u}$ & $\mathbf{M n}$ \\
\hline Coriander & $2.96 \mathrm{E}-03$ & $1.08 \mathrm{E}-02$ \\
Onion & $5.35 \mathrm{E}-03$ & $1.73 \mathrm{E}-02$ \\
Tomato & $4.43 \mathrm{E}-03$ & $1.34 \mathrm{E}-02$ \\
FAO NHO (2019) & $5.00 \mathrm{E}-02-$ & - \\
& $5.00 \mathrm{E}-01$ &
\end{tabular}

EDI (mg/person/day)

$\begin{array}{ccccc}\mathbf{Z n} & \mathbf{C d} & \mathbf{P b} & \mathbf{N i} & \mathbf{C o} \\ 1.83 \mathrm{E}-02 & 1.17 \mathrm{E}-04 & 1.06 \mathrm{E}-03 & 3.83 \mathrm{E}-04 & 2.36 \mathrm{E}-04 \\ 2.05 \mathrm{E}-02 & 1.09 \mathrm{E}-04 & 5.65 \mathrm{E}-04 & 4.63 \mathrm{E}-04 & 2.71 \mathrm{E}-04 \\ 1.56 \mathrm{E}-02 & 1.29 \mathrm{E}-04 & 4.24 \mathrm{E}-04 & 8.25 \mathrm{E}-04 & 2.03 \mathrm{E}-04 \\ 3.00 \mathrm{E}-01-1.00 \mathrm{E}+00 & 2.00 \mathrm{E}-01 & 3.00 \mathrm{E}-01 & - & -\end{array}$



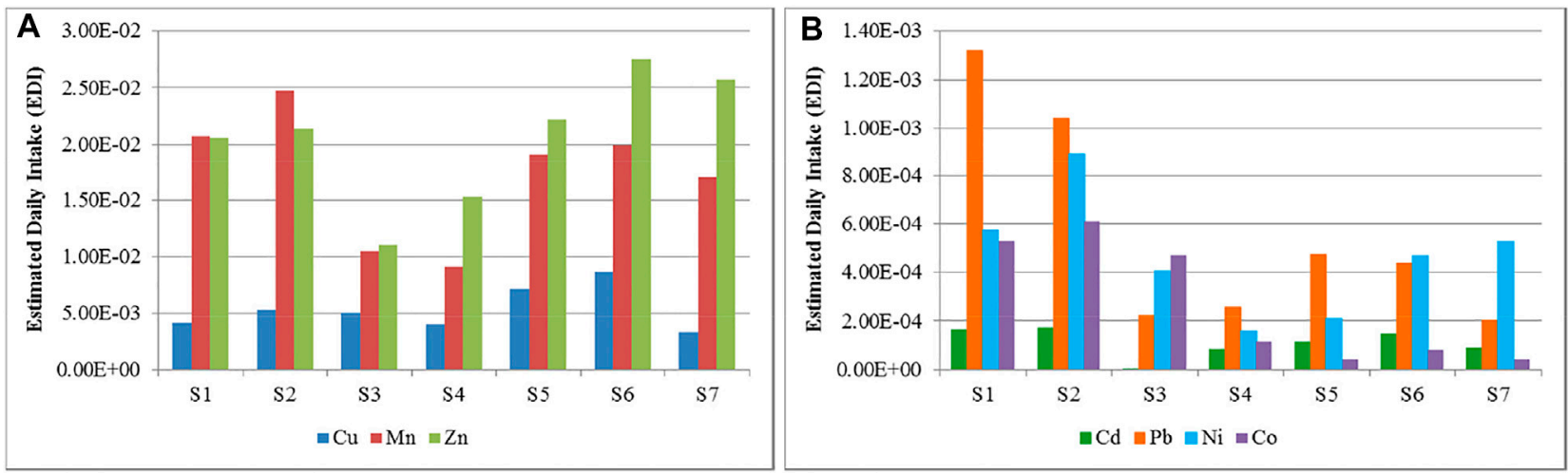

FIGURE $\mathbf{5}$ | (A,B) EDI of heavy metals in onion at different sampling sites.
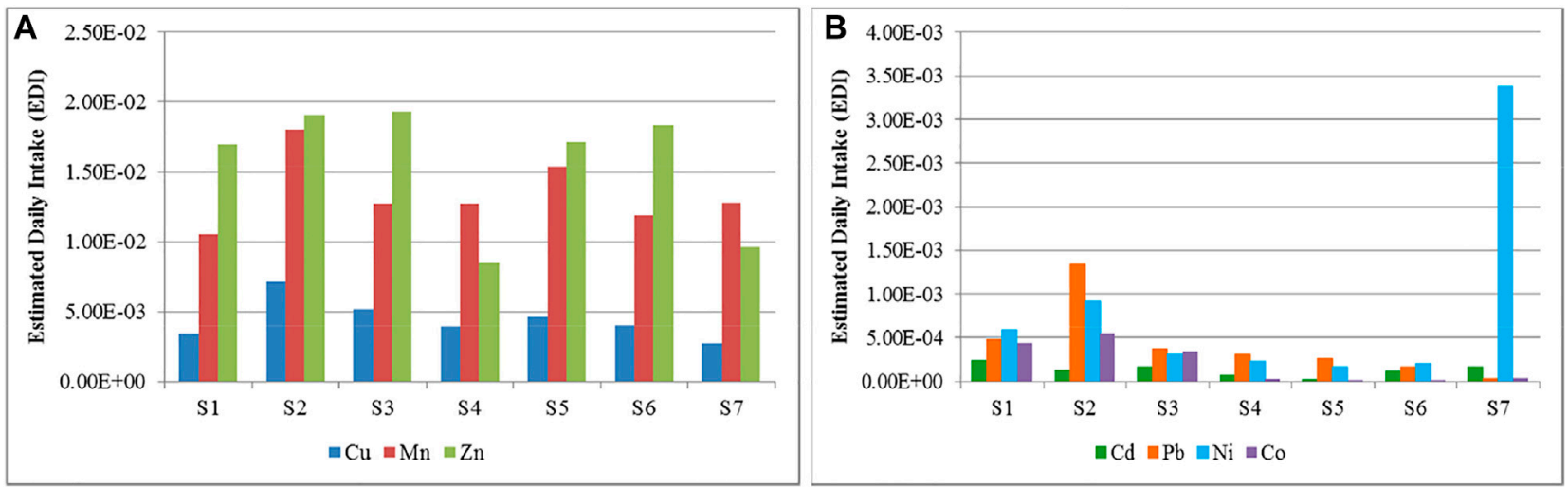

FIGURE 6 | (A,B) EDI of heavy metals in tomato at different sampling sites.

TABLE 6 | Target Hazard Quotient (THQ) of heavy metals for various vegetable crops.

\begin{tabular}{|c|c|c|c|c|c|c|c|c|}
\hline \multirow[t]{2}{*}{ Vegetables } & \multicolumn{7}{|c|}{ THQ } & \multirow[t]{2}{*}{ HRI } \\
\hline & Cd & $\mathrm{Pb}$ & $\mathrm{Cu}$ & Mn & $\mathrm{Zn}$ & $\mathrm{Ni}$ & Co & \\
\hline Coriander & 1.17E-01 & 3.02E-01 & 7.40E-03 & 2.35E-01 & 6.11E-02 & 1.91E-02 & 1.18E-02 & 7.54E-01 \\
\hline Onion & 1.09E-01 & 1.63E-01 & 1.34E-02 & 3.75E-01 & 6.84E-02 & 2.32E-02 & 1.37E-02 & 7.65E-01 \\
\hline Tomato & 1.29E-01 & 1.21E-01 & 1.13E-02 & 2.92E-01 & 5.19E-02 & 4.13E-02 & 1.02E-02 & 6.57E-01 \\
\hline
\end{tabular}

$\mathrm{Zn}>\mathrm{Ni}>\mathrm{Co}>\mathrm{Cu}$. In onion intake THQ of heavy metals was followed similar trends as $\mathrm{Mn}>\mathrm{Pb}>\mathrm{Cd}>\mathrm{Zn}>\mathrm{Ni}>\mathrm{Co}>\mathrm{Cu}$. However, the sequence of THQ of heavy metals in tomatoes followed a pattern in the order of $\mathrm{Mn}>\mathrm{Cd}>\mathrm{Pb}>\mathrm{Zn}>\mathrm{Ni}>\mathrm{Cu}>$ Co (Table 6). The THQ of Mn was highest in onion samples. It is noticeable that the highest THQ value was noted for Mn in onion. Despite the highest THQ of Mn in onion, it was not exceeding the safe value of 1 . THQ of all analyzed heavy metals in coriander, onion, and tomato was under the safe value of 1 , indicating that the vegetable consumption in these areas will not have any significant non-carcinogenic effects on humans.

The HRI value reflects the cumulative effects of various heavy metals in coriander, onion, and tomato consumption. Thus, it is evident from HRI that coriander, onion, and tomato consumptions are risk-free in the study area (Table 6). However, HRI value in coriander was slightly higher than the safe limit of one at S3 and S4 with their respective values of 1.03 and 1.01. Hence, it needs urgent attention to lower the heavy metals concentration in these sampling sites; otherwise, it may pose serious health hazards to humans in the near future.

\section{CONCLUSION}

The study results revealed that $\mathrm{Cd}, \mathrm{Pb}$, and $\mathrm{Zn}$ concentrations were higher than the Indian soil background values. In soil and coriander samples, Cd concentration exceeded the permissible limit. Likewise, the concentration of $\mathrm{Pb}$ exceeded the allowable 
concentration in coriander and onion. However, the average EDI and THQ of the study area for all investigated heavy metals were well within the permissible limit as notified by FAO/WHO (2019) for human consumption. But EDI and THQ values exceeded the safe limits at sampling sites two and 3. PCA analysis suggested that human activities plays vital role to the existing heavy metals concentration in the study area. Hence, it is strongly recommended to regularly monitor the soil and vegetable crops of the study area to avoid more accumulation, which may cause substantial non-carcinogenic health risks to the consumer of these vegetables in the near future.

\section{DATA AVAILABILITY STATEMENT}

The original contributions presented in the study are included in the article/supplementary material, further inquiries can be directed to the corresponding author.

\section{REFERENCES}

Adamiec, E., Jarosz-Krzemińska, E., and Wieszała, R. (2016). Heavy Metals from Non-exhaust Vehicle Emissions in Urban and Motorway Road Dusts. Environ. Monit. Assess. 188, 369. doi:10.1007/s10661-016-5377-1

Ahmad, K., Wajid, K., Khan, Z. I., Ugulu, I., Memoona, H., Sana, M., et al. (2019). Evaluation of Potential Toxic Metals Accumulation in Wheat Irrigated with Wastewater. Bull. Environ. Contam. Toxicol. 102 (6), 822-828. doi:10.1007/ s00128-019-02605-1

Alam, M., Khan, M., Khan, A., Zeb, S., Khan, M. A., Amin, N. u., et al. (2018). Concentrations, Dietary Exposure, and Human Health Risk Assessment of Heavy Metals in Market Vegetables of Peshawar, Pakistan. Environ. Monit. Assess. 190, 505. doi:10.1007/s10661-018-6881-2

Alsafran, M., Usman, K., Rizwan, M., Ahmed, T., and Al Jabri, H. (2021). The Carcinogenic and Non-carcinogenic Health Risks of Metal(oid)s Bioaccumulation in Leafy Vegetables: A Consumption Advisory. Front. Environ. Sci. 9, 742269. doi:10.3389/fenvs.2021.742269

Ametepey, S. T., Cobbina, S. J., Akpabey, F. J., Duwiejuah, A. B., and Abuntori, Z. N. (2018). Health Risk Assessment and Heavy Metal Contamination Levels in Vegetables from Tamale Metropolis, Ghana. FoodContamination 5 (1), 5. doi:10.1186/s40550-018-0067-0

Amin, N.-U., Hussain, A., Alamzeb, S., and Begum, S. (2013). Accumulation of Heavy Metals in Edible Parts of Vegetables Irrigated with Waste Water and Their Daily Intake to Adults and Children, District Mardan, Pakistan. Food Chem. 136, 1515-1523. doi:10.1016/j.foodchem.2012.09.058

Antoine, J. M. R., Fung, L. A. H., and Grant, C. N. (2017). Assessment of the Potential Health Risks Associated with the Aluminium, Arsenic, Cadmium and lead Content in Selected Fruits and Vegetables Grown in Jamaica. Toxicol. Rep. 4, 181-187. doi:10.1016/j.toxrep.2017.03.006

Anwar, S., Nawaz, M. F., Gul, S., Rizwan, M., Ali, S., and Kareem, A. (2016). Uptake and Distribution of Minerals and Heavy Metals in Commonly Grown Leafy Vegetable Species Irrigated with Sewage Water. Environ. Monit. Assess. 188 (9), 541. doi:10.1007/s10661-016-5560-4

Ashraf, I., Ahmad, F., Sharif, A., Altaf, A. R., and Teng, H. (2021). Heavy Metals Assessment in Water, Soil, Vegetables and Their Associated Health Risks via Consumption of Vegetables, District Kasur, Pakistan. SN Appl. Sci. 3, 552. doi:10.1007/s42452-021-04547-y

Awasthi, S. K. (2000). Prevention of Food Adulteration Act No. 37 of 1954. Central and State Rules as Amended for 1999. third ed. New Delhi: Ashoka Law House.

Baig, J. A., Bhatti, S., Kazi, T. G., and Afridi, H. I. (2018). Evaluation of Arsenic, Cadmium, Nickel and Lead in Common Spices in Pakistan. Biol. Trace Elem. Res. 187, 586-595. doi:10.1007/s12011-018-1400-4

\section{AUTHOR CONTRIBUTIONS}

NG: Conceptualization, Methodology, Writing-Original Draft, Writing- Review and Editing. VK: Supervision. KY: Writing-Original Draft, Formal analysis. MC-P: Writing-Original Draft, Formal analysis. SP: Writing-Original Draft, Writing-Review and Editing. B-HJ and SK: Data curation, Formal analysis. MA: Formal analysis, Resources, Writing-Review and Editing. AA: Writing-Review and Editing.

\section{FUNDING}

The authors thank Taif University Researchers, supporting project number TURSP-2020/91, Taif University, Saudi Arabia. Funding for this research was (partially provided by the Projects SFRH/BPD/71030/2010, Project UID/GEO/04035/ 2019 (Geobiotec Research Centre) financed by FCT-Fundação para a Ciência e Tecnologia.

Bounar, A., Boukaka, K., and Leghouchi, E. (2020). Determination of Heavy Metals in Tomatoes Cultivated under green Houses and Human Health Risk Assessment. Qas 12 (1), 76-86. doi:10.15586/qas2019.639

Cgwb (2017). Report on Aquifer Mapping and Ground Water Management Plan, Jhansi District, Uttar Pradesh. Lucknow: Central Ground Water Board, Northern Region.

Cherfi, A., Cherfi, M., Maache-Rezzoug, Z., and Rezzoug, S.-A. (2016). Risk Assessment of Heavy Metals via Consumption of Vegetables Collected from Different Supermarkets in La Rochelle, France. Environ. Monit. Assess. 188, 136. doi:10.1007/s10661-016-5140-7

FAO (2017). Water for Sustainable Food and Agriculture: A Report Produced for the G20 Presidency of Germany. Rome: Food and Agriculture Organization of the United Nations. Available at: https://www.fao.org/ 3/i7959e/i7959e.pdf.

FAO/WHO (Food and Agriculture Organization/World Health Organization) (2019). General Standard for Contaminants and Toxins in Food and Feed. Codex Alimentarius Commission. Available at: http://www.fao.org/fao-whocodexalimentarius/sh-proxy/en/?lnk=1\&url=https\%253A\%252F\%252Fworkspace. fao.org\%252Fsites\%252Fcodex\%252FStandards\%252FCXS\%2B193-1995\% 252FCXS_193e.pdf.

Filimon, M. N., Caraba, I. V., Popescu, R., Dumitrescu, G., Verdes, D., Petculescu Ciochina, L., et al. (2021). Potential Ecological and Human Health Risks of Heavy Metals in Soils in Selected Copper Mining Areas-A Case Study: The Bor Area. Ijerph 18 (4), 1516. doi:10.3390/ijerph18041516

Flora, S. J. S. (2014). "Metals," in Biomarkes in Toxicology. Editor R. Gupta (Elsevier), 485-519. doi:10.1016/b978-0-12-404630-6.00029-4

Fonge, B. A., Larissa, M. T., Egbe, A. M., Afanga, Y. A., Frum, N. G., and NgoleJeme, V. M. (2021). An Assessment of Heavy Metal Exposure Risk Associated with Consumption of Cabbage and Carrot Grown in a Tropical Savannah Region. Int. J. Environ. Health Sustainability 7 (1), 1-19. doi:10.1080/27658511. 2021.1909860

Gan, Y., Wang, L., Yang, G., Dai, J., Wang, R., and Wang, W. (2017). Multiple Factors Impact the Contents of Heavy Metals in Vegetables in High Natural Background Area of China. Chemosphere 184, 1388-1395. doi:10.1016/j. chemosphere.2017.06.072

Gebeyehu, H. R., and Bayissa, L. D. (2020). Levels of Heavy Metals in Soil and Vegetables and Associated Health Risks in Mojo Area, Ethiopia. PLoS One 15, e0227883. doi:10.1371/journal.pone.0227883

Guo, G. L., Zhou, Q. X., Koval, P. V., and Belogolova, G. A. (2006). Speciation Distribution of $\mathrm{Cd}, \mathrm{Pb}, \mathrm{Cu}$, and $\mathrm{Zn}$ in Contaminated Phaeozem in north-east China Using Single and Sequential Extraction Procedures. Soil Res. 44 (2), 135-142. doi:10.1071/sr05093

Gupta, N., Yadav, K. K., Kumar, V., Cabral-Pinto, M. M. S., Alam, M., Kumar, S., et al. (2021b). Appraisal of Contamination of Heavy Metals and Health Risk in 
Agricultural Soil of Jhansi City, India. Environ. Toxicol. Pharmacol. 88, 103740. doi:10.1016/j.etap.2021.103740

Gupta, N., Yadav, K. K., Kumar, V., Krishnan, S., Kumar, S., Nejad, Z. D., et al. (2021a). Evaluating Heavy Metals Contamination in Soil and Vegetables in the Region of North India: Levels, Transfer and Potential Human Health Risk Analysis. Environ. Toxicol. Pharmacol. 82, 103563. doi:10.1016/j.etap.2020. 103563

Gupta, N., Yadav, K. K., Kumar, V., Kumar, S., Chadd, R. P., and Kumar, A. (2019). Trace Elements in Soil-Vegetables Interface: Translocation, Bioaccumulation, Toxicity and Amelioration - a Review. Sci. Total Environ. 651, 2927-2942. doi:10.1016/j.scitotenv.2018.10.047

Haque, M. M., Niloy, N. M., Khirul, M. A., Alam, M. F., and Tareq, S. M. (2021). Appraisal of Probabilistic Human Health Risks of Heavy Metals in Vegetables from Industrial, Non-industrial and Arsenic Contaminated Areas of Bangladesh. Heliyon 7, e06309. doi:10.1016/j.heliyon.2021.e06309

IARC (2014). IARC Monographs on the Evaluation of Carcinogenic Risks to Humans. Lyon, France: International Agency for Research on Cancer.

Ihedioha, J. N., Okoye, C. O. B., and Onyechi, U. A. (2014). Health Risk Assessment of Zinc, Chromium, and Nickel from Cow Meat Consumption in an Urban Nigerian Population. Int. J. Occup. Environ. Health 20, 281-288. doi:10.1179/ 2049396714y.0000000075

Islam, M. S., Ahmed, M. K., Habibullah-Al-Mamun, M., Raknuzzaman, M., Ali, M. M., and Eaton, D. W. (2016). Health Risk Assessment Due to Heavy Metal Exposure from Commonly Consumed Fish and Vegetables. Environ. Syst. Decis. 36, 253-265. doi:10.1007/s10669-016-9592-7

Jaishankar, M., Tseten, T., Anbalagan, N., Mathew, B. B., and Beeregowda, K. N. (2014). Toxicity, Mechanism and Health Effects of Some Heavy Metals. Interdiscip. Toxicol. 7, 60-72. doi:10.2478/intox-2014-0009

Jan, F. A., Ishaq, M., Ihsanullah, I., and Asim, S. M. (2010). Multivariate Statistical Analysis of Heavy Metals Pollution in Industrial Area and its Comparison with Relatively Less Polluted Area: a Case Study from the City of Peshawar and District Dir Lower. J. Hazard. Mater. 176, 609-616. doi:10.1016/j.jhazmat.2009. 11.073

Khan, A., Khan, S., Khan, M. A., Qamar, Z., and Waqas, M. (2015). The Uptake and Bioaccumulation of Heavy Metals by Food Plants, Their Effects on Plants Nutrients, and Associated Health Risk: a Review. Environ. Sci. Pollut. Res. 22 (18), 13772-13799. doi:10.1007/s11356-015-4881-0

Khan, Z. I., Ugulu, I., Ahmad, K., Yasmeen, S., Noorka, I. R., Mehmood, N., et al. (2018). Assessment of Trace Metal and Metalloid Accumulation and Human Health Risk from Vegetables Consumption through Spinach and Coriander Specimens Irrigated with Wastewater. Bull. Environ. Contam. Toxicol. 101, 787-795. doi:10.1007/s00128-018-2448-8

Kladsomboon, S., Jaiyen, C., Choprathumma, C., Tusai, T., and Apilux, A. (2020). Heavy Metals Contamination in Soil, Surface Water, Crops, and Resident Blood in Uthai District, Phra Nakhon Si Ayutthaya, Thailand. Environ. Geochem. Health 42, 545-561. doi:10.1007/s10653-019-00388-2

Kumar, S., Prasad, S., Yadav, K. K., Shrivastava, M., Gupta, N., Nagar, S., et al. (2019a). Hazardous Heavy Metals Contamination of Vegetables and Food Chain: Role of Sustainable Remediation Approaches - A Review. Environ. Res. 179, 108792. doi:10.1016/j.envres.2019.108792

Kumar, V., Sharma, A., Kaur, P., Singh Sidhu, G. P., Bali, A. S., Bhardwaj, R., et al. (2019b). Pollution Assessment of Heavy Metals in Soils of India and Ecological Risk Assessment: A State-Of-The-Art. Chemosphere 216, 449-462. doi:10.1016/ j.chemosphere.2018.10.066

Letshwenyo, M. W., and Mokokwe, G. (2020). Accumulation of Heavy Metals and Bacteriological Indicators in Spinach Irrigated with Further Treated Secondary Wastewater. Heliyon 6, e05241. doi:10.1016/j.heliyon.2020.e05241

Manea, D. N., Ienciu, A. A., Ştef, R., Şmuleac, I. L., Gergen, I. I., and Nica, D. V. (2020). Health Risk Assessment of Dietary Heavy Metals Intake from Fruits and Vegetables Grown in Selected Old Mining Areas-A Case Study: The Banat Area of Southern Carpathians. Ijerph 17, 5172. doi:10.3390/ijerph17145172

Moghtaderi, T., Mahmoudi, S., Shakeri, A., and Masihabadi, M. H. (2018). Heavy Metals Contamination and Human Health Risk Assessment in Soils of an Industrial Area, Bandar Abbas - South Central Iran. Hum. Ecol. Risk Assess. Int. J. 24 (4), 1058-1073. doi:10.1080/10807039.2017.1405723

Mohammadi, A. A., Zarei, A., Majidi, S., Ghaderpoury, A., Hashempour, Y., Saghi, M. H., et al. (2019). Carcinogenic and Non-carcinogenic Health Risk
Assessment of Heavy Metals in Drinking Water of Khorramabad, Iran. MethodsX 6, 1642-1651. doi:10.1016/j.mex.2019.07.017

Mohammadi, M. J., Yari, A. R., Saghazadeh, M., Sobhanardakani, S., Geravandi, S., Afkar, A., et al. (2017). A Health Risk Assessment of Heavy Metals in People Consuming Sohan in Qom, Iran. Toxin Rev. 37 (4), 278-286. doi:10.1080/ 15569543.2017.1362655

Mohammed Abdul, K. S., Jayasinghe, S. S., Chandana, E. P. S., Jayasumana, C., and De Silva, P. M. C. S. (2015). Arsenic and Human Health Effects: A Review. Environ. Toxicol. Pharmacol. 40 (3), 828-846. doi:10.1016/j.etap.2015.09.016

Muhammad, M., Habib, I. Y., Hamza, I., Mikail, T. A., Yunusa, A., Muhammad, I. A., et al. (2021). Heavy Metals Contamination of Agricultural Land and Their Impact on Food Safety. Ejnfs 13 (1), 104-111. doi:10.9734/ejnfs/2021/ v13i130354

Njagi, J. M., Akunga, D. N., Njagi, M. M., Ngugi, M. P., and Njagi, E. M. N. (2017). Heavy Metal Concentration in Vegetables Grown Around Dumpsites in Nairobi City County, Kenya. World Environ. 7 (2), 49-56.

Prasad, S., Yadav, K. K., Kumar, S., Gupta, N., Cabral-Pinto, M. M. S., Rezania, S., et al. (2021). Chromium Contamination and Effect on Environmental Health and its Remediation: A Sustainable Approaches. J. Environ. Manage. 285, 112174. doi:10.1016/j.jenvman.2021.112174

Ramesh, H. L., and Murthy, V. N. Y. (2012). Assessment of Heavy Metal Contamination in green Leafy Vegetables Grown in Bangalore Urban District of Karnataka. Adv. Life Sci.Technol. 6, 40-51.

Sharma, A., Katnoria, J. K., and Nagpal, A. K. (2016). Heavy Metals in Vegetables: Screening Health Risks Involved in Cultivation along Wastewater drain and Irrigating with Wastewater. SpringerPlus 5, 488. doi:10.1186/s40064-0162129-1

Sharma, S., Nagpal, A. K., and Kaur, I. (2018). Heavy Metal Contamination in Soil, Food Crops and Associated Health Risks for Residents of Ropar Wetland, Punjab, India and its Environs. Food Chem. 255, 15-22. doi:10.1016/j. foodchem.2018.02.037

Simonsen, L. O., Brown, A. M., Harbak, H., Kristensen, B. I., and Bennekou, P. (2011). Cobalt Uptake and Binding in Human Red Blood Cells. Blood Cell Mol. Dis. 46, 266-276. doi:10.1016/j.bcmd.2011.02.009

Singh, U., and Praharaj, C. S. (2017). Practical Manual- Chemical Analysis of Soil and Plant Samples. Kanpur, Uttar Pradesh, India: ICAR-Indian Institute of Pulses Research.Available at: https://krishi.icar.gov.in/jspui/ bitstream/123456789/12719/1/Print-PDF-IIPR-Pocket\%20Guide-1-32018.pdf.

Sun, C., Zhang, Z., Cao, H., Xu, M., and Xu, L. (2019). Concentrations, Speciation, and Ecological Risk of Heavy Metals in the Sediment of the Songhua River in an Urban Area with Petrochemical Industries. Chemosphere 219, 538-545. doi:10. 1016/j.chemosphere.2018.12.040

Taylor, C., Golding, J., and Emond, A. (2015). Adverse Effects of Maternal lead Levels on Birth Outcomes in the ALSPAC Study: a Prospective Birth Cohort Study. Bjog: Int. J. Obstet. Gy 122, 322-328. doi:10.1111/1471-0528.12756

Taylor, M., and Kruger, N. (2020). Tyre Weights an Overlooked Diffuse Source of lead and Antimony to Road Runoff. Sustainability 12, 6790. doi:10.3390/ su12176790

Tefera, M., and Teklewold, A. (2021). Health Risk Assessment of Heavy Metals in Selected Ethiopian Spices. Heliyon 7, e07048. doi:10.1016/j.heliyon.2021.e07048

USEPA (2021). Regional Screening Levels (RSLs)-Generic Tables. Washington, DC, USA: United States Environmental Protection Agency. Available at: https:// www.epa.gov/risk/regional-screening-levels-rsls-generic-tables.

USEPA (1989). Risk Assessment Guidance for Superfund, Volume I: Human Health Evaluation Manual; Office of Soild Waste and Emergency Response. Washington, DC, USA: United States Environmental Protection Agency.

USEPA (1991). Risk Assessment Guidance for Superfund. Volume I - Human Health Evaluation Manual (Part B, Development of Risk-Based Preliminary Remediation Goals). Washington, DC, USA: Office of Research and Development, United States Environmental Protection Agency.

USEPA (2002). Supplemental Guidance for Developing Soil Screening Levels for Superfund SitesOffice of Solid Waste and Emergency Response. Washington, DC, USA: United States Environmental Protection Agency.

Wang, Y., Su, H., Gu, Y., Song, X., and Zhao, J. (2017). Carcinogenicity of Chromium and Chemoprevention: A Brief Update. Ott Vol. 10, 4065-4079. doi:10.2147/ott.s139262 
Wongsasuluk, P., Chotpantarat, S., Siriwong, W., and Robson, M. (2014). Heavy Metal Contamination and Human Health Risk Assessment in Drinking Water from Shallow Groundwater wells in an Agricultural Area in Ubon Ratchathani Province, Thailand. Environ. Geochem. Health 36 (1), 169-182. doi:10.1007/ s10653-013-9537-8

Wuana, R. A., and Okieimen, F. E. (2011). Heavy Metals in Contaminated Soils: A Review of Sources, Chemistry, Risks and Best Available Strategies for Remediation. ISRN Ecol. 12, 402647. doi:10.5402/2011/402647

Yadav, R. K., Minhas, P. S., Lal, K., Chaturvedi, R. K., Yadav, G., and Verma, T. P. (2015). Accumulation of Metals in Soils, Groundwater and Edible Parts of Crops Grown under Long-Term Irrigation with Sewage Mixed Industrial Effluents. Bull. Environ. Contam. Toxicol. 95 (2), 200-206. doi:10.1007/ s00128-015-1547-z

Zafarzadeh, A., Rahimzadeh, H., and Mahvi, A. H. (2018). Health Risk Assessment of Heavy Metals in Vegetables in an Endemic Esophageal Cance Region in Iran. Health Scope 7 (3), e12340. doi:10.5812/ jhealthscope. 12340

Zhou, H., Yang, W.-T., Zhou, X., Liu, L., Gu, J.-F., Wang, W.-L., et al. (2016). Accumulation of Heavy Metals in Vegetable Species Planted in Contaminated Soils and the Health Risk Assessment. Ijerph 13, 289. doi:10.3390/ ijerph13030289
Zwolak, A., Sarzyńska, M., Szpyrka, E., and Stawarczyk, K. (2019). Sources of Soil Pollution by Heavy Metals and Their Accumulation in Vegetables: A Review. Water Air Soil Pollut. 230 (7), 164. doi:10.1007/s11270-019-4221-y

Conflict of Interest: The authors declare that the research was conducted in the absence of any commercial or financial relationships that could be construed as a potential conflict of interest.

Publisher's Note: All claims expressed in this article are solely those of the authors and do not necessarily represent those of their affiliated organizations, or those of the publisher, the editors and the reviewers. Any product that may be evaluated in this article, or claim that may be made by its manufacturer, is not guaranteed or endorsed by the publisher.

Copyright (c) 2022 Gupta, Yadav, Kumar, Prasad, Cabral-Pinto, Jeon, Kumar, Abdellattif and Alsukaibia. This is an open-access article distributed under the terms of the Creative Commons Attribution License (CC BY). The use, distribution or reproduction in other forums is permitted, provided the original author(s) and the copyright owner(s) are credited and that the original publication in this journal is cited, in accordance with accepted academic practice. No use, distribution or reproduction is permitted which does not comply with these terms. 